Original Article

\title{
HEPATOPROTECTIVE ACTIVITY COMBINATION OF CURANGA FEL-TERRAE LOUR LEAVES AND CURCUMA HEYNEANA VALETON AND ZIJP RHIZOME IN RAT INDUCED BY COMBINATION OF RIFAMPIN AND ISONIAZID
}

\author{
MARIANNE1, JESSY CHRESTELLA ${ }^{2}$, MARIA ANDRIANI GINTING1, AMINAH DALIMUNTHE1, ROSNANI NASUTION³ \\ 1Faculty of Pharmacy, Universitas Sumatera Utara, Padang Bulan, Medan 20155, Indonesia, ${ }^{2}$ Faculty of Medicine, Universitas Sumatera Utara, \\ Padang Bulan, Medan 20155, Indonesia, ${ }^{3}$ Faculty of Mathematic and Natural Sciences, Syiah Kuala University, Banda Aceh, Indonesia 23111 \\ Email: marianne80@usu.ac.id
}

Received: 09 Dec 2016 Revised and Accepted: 09 Mar 2017

\section{ABSTRACT}

Objective: The liver is a vital organ in the body, it is often exposured to the xenobiotics that can cause injury. Pugun tano (Curanga fel-terrae) and temu giring (Curcuma heyneana) are plants that have been claimed to cure many ailments including protecting the liver. But the hepatoprotective properties of the combination of these plants has not been well studied. In this regard, the current study was undertaken to evaluate the activity combination of those plants.

Methods: The male Wistar rats were divided into 6 groups, group I was a negative control (CMC-Na); group II-IV were the treatment groups and were given combination extracts at the doses of $50 \mathrm{mg} / \mathrm{kg}, 75 \mathrm{mg} / \mathrm{kg}$ and $100 \mathrm{mg} / \mathrm{kg}$ respectively; group V was positive control (catechin) and group VI was normal control. All of groups except group VI were given combination rifampin $100 \mathrm{mg} / \mathrm{kg}$ and isoniazid $50 \mathrm{mg} / \mathrm{kg}$ for $15 \mathrm{~d}$ along with administration of extracts. At the day 16, rats were sacrificed. Histopathology of the liver and biochemical assay of blood was done at the end of the administration.

Results: The administration of the combination of $C$. fel-terrae and $C$. heyneana at the doses of 75 and $100 \mathrm{mg} / \mathrm{kg}$ significantly inhibited the elevation of aspartate aminotransferase (AST) and alanine transaminase (ALT) compared to negative control ( $<<0.05$ ). Histopathological assessment of the liver was comparable to the normal control $(\mathrm{p}>0.05)$.

Conclusion: The combination of $C$. fel-terrae and $C$. heyneana at the dose of 75 and $100 \mathrm{mg} / \mathrm{kg}$ is able to protect the liver from damage induced by rifampin and isoniazid.

Keywords: Curanga fel-terrae, Curcuma heyneana, Hepatoprotective, Rifampin, Isoniazid

(C) 2017 The Authors. Published by Innovare Academic Sciences Pvt Ltd. This is an open access article under the CC BY license (http://creativecommons.org/licenses/by/4.0/) DOI: http://dx.doi.org/10.22159/ijpps.2017v9i5.16528

\section{INTRODUCTION}

Drug-induced liver injury (DILI) is serious problem commonly associated with using of particular drugs like those used in the treatment of tuberculosis [1]. This situation can limit the use of antituberculosis drugs and can cause the failure of therapy. Hence, newer strategies must be found to address the problem in order to enhance the compliance of tuberculosis patients [2].

C. heyneana is known as temu giring or kuning gajah. It is an annual plant that has been used as a material of traditional medicine (jamu) in Indonesia, Malaysia and even in China for traditional Chinese Medicine (TCM). It has efficacy as anthelmintic because it contains citric piperazine which is able to tackle Ascaris [3]. This plant is abushes, height about 1 until $2 \mathrm{~m}$, has rhizome and from Zingiberaceae tribe [4]. Genus curcuma contains the sort of chemical constituents and has broad bioactivities such as anti-oxidants, antitumor and anti-inflammatory as well as antimicrobial [5-6]. Constituents from $C$. heyneanaare curcumenol, isocurcumenol, along with phytosterols, stigmasterol and alpha-sitosterol showed moderate inhibition against CEM-SS in cytotoxic assay [6]. It is also inhibited protein tyrosine phosphatase 1B (PTP1B) which is considered to be involved in the etiology of diabetes mellitus, neural diseases regulation of allergy and inflammation or they are even considered to be responsible for the pathogens [7-8].

C. fel-terrae or pugun tano is a smooth, prostrate herb. It is also known as Picria fel-terrae. Its common names is sagai-uak or curanja. It has been used traditionally in Karo district, North Sumatera, Indonesia, stimulant and treat diabetes mellitus as well as malaria. Previous reports said that it has pharmacological activities such as a diuretic, cardioprotective, induced apoptosis, cell cycle arrest and suppressing cyclin D1 and Bcl-2 expression, antidiabetic and inhibitory effect to acetylcholine muscarinic-3 receptors which is related as anti-asthma [9-13].

Previous research has reported that the ethanolic extract of $C$. $f e l$ terrae leaves at the dose of $125 \mathrm{mg} / \mathrm{kg}$ can protect the liver from the damage caused by high doses of paracetamol [14]. Other authors have also mentioned that ethanolic extract of $C$. heyneana rhizome at the dose of $125 \mathrm{mg} / \mathrm{kg}$ can protect the liver against injury caused by high doses paracetamol as well as the combination of antituberculosis drugs rifampin and isoniazid [15-16]. The activity was comparable to catechin which has been recommended as hepatoprotective agent [17]. Based on the potency of these plants, this study is aimed at exploring the combination of both extracts to establish an effective dose and possible synergistic effect from the extracts in protecting against liver damage induced by the antituberculosis drugs rifampin and isoniazid. The long-term aim was to formulate this extracts into a phytopharmaceutical agent for possible use along with the conventional antituberculosis drugs to prevent the associated liver damage.

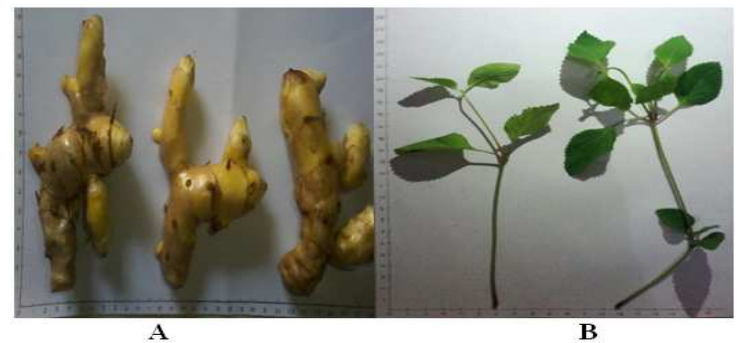

Fig. 1: Picture of the plants, (A) rhizome of $C$. heyneana; (B) leaves of $C$. fel-terrae 


\section{MATERIALS AND METHODS}

\section{Plant material and extraction}

C. fel-terrae and C. heyneana were collected from Pancur Batu subdistrict, Deli Serdang district. Collected plant samples were washed under running tap water, dried, powdered in a grinder and stored in airtight jars. The plant identification was confirmed by The Indonesian Academy of Sciences, Indonesia Number 1775/IPH.1.01/ If.07/ VIII/2016. As much as 220 gram the dried leaves of $C$. fel-terrae and 212 gram rhizome of $C$. heyneana were extracted with maceration method using $2.5 \mathrm{~L}$ of ethanol until discoloration, then ethanol was evaporated at $40^{\circ} \mathrm{C}$ in a rotary vacuum evaporator. The yield of $C$. felterrace leaves extract was 26.55 gram $(12.07 \%)$ and for $C$. heyneana was 25.48 gram $(12.02 \%)$. The extracts were stored at $2-8{ }^{\circ} \mathrm{C}$ and used for determining the activity. The percentage yield of extracts was calculated by the following formula:

$$
\text { Yield } \%=\frac{\text { weight of dry crude extract obtained }(\mathrm{g})}{\text { weight of plant material before extraction (g) }} \times 100
$$

\section{Chemicals and reagents}

Rifampin (Sandoz, Indonesia), isoniazid (Sandoz, Indonesia), ethanol (Merck, Germany), sodium carboxymethyl cellulose (CMC-Na) (Sigma-Aldrich), catechin (Sigma-Aldrich), reagent kit alanine aminotransferase (ALT) (DiaSys ${ }^{\circledR}$ ), reagen kit aspartate amino- transferase (AST) (DiaSys ${ }^{\circledR}$ ), neutral buffered formalin 10\%, and hematoxylin and eosin stain. All biochemical measurements were performed using UV-Vis spectrophotometer (Thermo scientific).

\begin{abstract}
Animals
All treatments to the animal and procedure were evaluated by Ethic Committee Faculty of Medicine, University of Sumatera Utara No. 653/TGL/KEPK FK USU-RSUP HAM/2016. Thirty male Wistar rats $(180 \pm 20 \mathrm{~g})$ were obtained from Animal Breeding Unit, Faculty of Pharmacy, University of Sumatera Utara. The animals were kept under standard laboratory conditions and allowed a natural lightdark cycle. The rats were fed on a standard pellet diet and provided access to water ad libitum.
\end{abstract}

\section{Hepatoprotective activity}

After $7 \mathrm{~d}$ of acclimatisation, animals were divided into six groups of five rats. Liver damage was induced by the administration of isoniazid $50 \mathrm{mg} / \mathrm{kg}$ and rifampin $100 \mathrm{~g} / \mathrm{kg}$ [18]. Every day the rats were given combination extracts of $C$. fel-terrae and $C$. heyneana as well as isoniazid and rifampin as long as $15 \mathrm{~d}$. On the $16^{\text {th }}$ day, all rats were sacrificed by mild ether anesthesia. The blood and the liver were withdrawn in order to be determined the activity of ALT and AST enzymes, microscopic and macroscopic of the liver (Table 1).

Table 1: Experimental design of hepatoprotective activity from combination of $C$. fel-terrae and $C$. heyneana

\begin{tabular}{ll}
\hline Group & Treatment \\
\hline I: (negative control) & CMC-Na 0,5\%+isoniazid $50 \mathrm{mg} / \mathrm{kg}+$ rifampin $100 \mathrm{mg} / \mathrm{kg}$ \\
II: (dose of $50 \mathrm{mg} / \mathrm{kg})$ & EECF $50 \mathrm{mg} / \mathrm{kg}+$ EECH $50 \mathrm{mg} / \mathrm{kg}+$ isoniazid $50 \mathrm{mg} / \mathrm{kg}+\mathrm{rifampin} 100 \mathrm{mg} / \mathrm{kg}$ \\
III: (dose of $75 \mathrm{mg} / \mathrm{kg})$ & EECF $75 \mathrm{mg} / \mathrm{kg}+$ EECH $75 \mathrm{mg} / \mathrm{kg}+$ isoniazid $50 \mathrm{mg} / \mathrm{kg}+\mathrm{rifampin} 100 \mathrm{mg} / \mathrm{kg}$ \\
IV: (dose of $100 \mathrm{mg} / \mathrm{kg})$ & EECF $100 \mathrm{mg} / \mathrm{kg}+$ EECH $100 \mathrm{mg} / \mathrm{kg}+$ isoniazid $50 \mathrm{mg} / \mathrm{kg}+\mathrm{rifampin} 100 \mathrm{mg} / \mathrm{kg}$ \\
V: (positive control) & catechin $2 \mathrm{mg} / \mathrm{kg}+$ isoniazid $50 \mathrm{mg} / \mathrm{kg}+$ rifampin $100 \mathrm{mg} / \mathrm{kg}$ \\
VI: (normal control) & Without treatment \\
\hline
\end{tabular}

$\mathrm{EECF}=$ ethanolic extract of $C$. fel-terrae; $\mathrm{EECH}=$ ethanolic extract of $C$. Heyneana

\section{Analysis of liver enzymes}

The blood sample was collected from the vein of the heart of each animal. Serum was separated and stored at $2-8^{\circ} \mathrm{C}$ before it was used to determine the activity of AST and ALT. The liver was taken for histopathological analysis.

\section{Macroscopic assessment of the liver}

Liver obtained from the rats were washed with $\mathrm{NaCl} 0.9 \%$. The observation was done toward the intensity of colour, texture of liver surface as well as organ weight in order to calculate the liver relative index.

$$
\text { Liver relative index }(\%)=\frac{\text { weight of liver }(\mathrm{g})}{\text { final body weight }(\mathrm{g})} \times 100
$$

\section{Microscopic of the liver}

The liver tissue was treated with $10 \%(\mathrm{v} / \mathrm{v})$ formalin buffer and then embedded in paraffin. Slicing was done using a microtome and stained with haematoxylin and eosin and observed by using a microscope.

\section{Statistical analysis}

Results were expressed as Means \pm Standard error (SE). Statistical analysis were carried out using one-way analysis of variance followed by a Tukey post-hoc test (SPSS Version 18; SPSS Inc., Chicago, IL, USA). Statistical significance was set at $\mathrm{P}<0.05$. The $p$ values are presented with obtained data.

\section{RESULTS}

\section{Macropathology liver organ}

Table 2 and fig. 2 revealed the macromorphological study which has been done on the liver. The liver of negative control has white spot. Unlike negative control, the other groups have no white spot in the liver. It means that there is protection from the extracts to the liver. The colour of negative control and a dose of $50 \mathrm{mg} / \mathrm{kg}$ is pale red, whereas the others red to reddish-brown.

Table 2: Macropathology of liver organ and liver relative index from rats. Data were presented as mean \pm SEM $(n=5)$

\begin{tabular}{llll}
\hline Group & \multicolumn{2}{l}{ Parameter of observation } & Liver relative index mean \pm SEM \\
\cline { 2 - 3 } & Colour & Texture & $4.61 \pm 0.16$ \\
\hline Negative control & Pale red & Smooth with some white spots & $4.51 \pm 0.20$ \\
Dose of $50 \mathrm{mg} / \mathrm{kg}$ & Red & Smooth & $3.14 \pm 0.11^{\mathrm{abc}}$ \\
Dose of $75 \mathrm{mg} / \mathrm{kg}$ & Reddish-brown & Smooth & $3.61 \pm 0.04^{\mathrm{abc}}$ \\
Doseof $100 \mathrm{mg} / \mathrm{kg}$ & Reddish-brown & Smooth & $3.35 \pm 0.17^{\mathrm{ab}}$ \\
Positive control & Reddish-brown & Smooth & $3.09 \pm 0.06^{\mathrm{ac}}$ \\
Normal control & Reddish-brown & Smooth & \\
\hline
\end{tabular}

significantly different wit negative control group $(\mathrm{p}<0.05)$, same as a normal control group, ${ }^{\mathrm{c}}$ same as positive control group ( $\left.\mathrm{p}>0.05\right)$ 


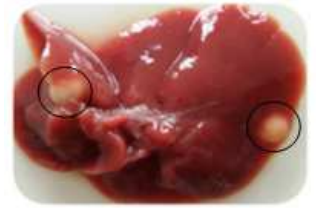

A

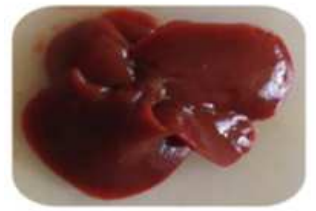

D

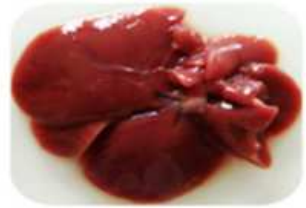

B

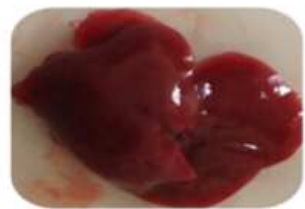

E

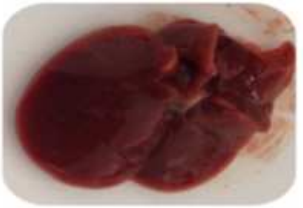

$\mathrm{C}$

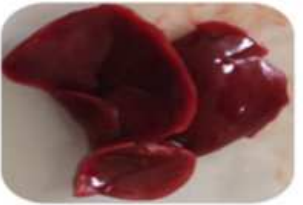

F

Fig. 2: Macroscopic of the liver, (A) negative control, the liver with white spot and the colour is pale red; (B) dose of $50 \mathrm{mg} / \mathrm{kg}$, the liver has no spot and the colour is pale red; (C) dose of $75 \mathrm{mg} / \mathrm{kg}$, the liver has no spot and the colour is reddish brown; (D) dose of $100 \mathrm{mg} / \mathrm{kg}$, the liver has no spot and the colour is reddish brown; (E) positive control, the liver has no spot and the colour is reddish brown; (F) normal control, the liver has no spot and the colour is reddish brown

Organ-to-body weight ratio shows that injury causes the weight of the liver is increase significantly compared to the normal control group $(\mathrm{p}<0.05)$. However, the weight of the liver from groups at the doses of 75 and $100 \mathrm{mg} / \mathrm{kg}$ did not increase. Therefore administration of extracts is able to prevent the injury in the liver.

\section{Biochemical determination}

Based on table 3 and fig. 3, ALT of the negative control group increased significantly due to induction of rifampin and isoniazid compared to normal group $(\mathrm{p}<0.05)$. Administration combination of extracts at the dose of $50 \mathrm{mg} / \mathrm{kg}$ could not prevent elevation of
ALT. Whereas at the doses of 75 and $100 \mathrm{mg} / \mathrm{kg}$, the combination of extracts was able to prevent increasing of ALT compared to negative control group $(\mathrm{p}<0.05)$. Moreover, the ALT value of those groups was the same as normal control. It means that groups at the doses of 75 and $100 \mathrm{mg} / \mathrm{kg}$ had hepatoprotective activity. Besides ALT, AST increased significantly compared to normal group $(\mathrm{p}<0.05)$. Administration combination of extracts at the dose of $50 \mathrm{mg} / \mathrm{kg}$ could not prevent elevation of AST. Whereas at the doses of 75 and $100 \mathrm{mg} / \mathrm{kg}$, the combination of extracts was able to prevent the elevation of AST compared to negative control group $(\mathrm{p}<0.05)$.

Table 3: Hepatoprotective activity from combination of extracts toward biochemical parameter. Data were presented as mean \pm SEM ( $n=5$ )

\begin{tabular}{lll}
\hline Group & ALT (U/l) mean \pm SEM & AST (U/I) mean \pm SEM \\
\hline Negative control & $287.00 \pm 58.89$ & $251.00 \pm 32.91$ \\
Dose of $50 \mathrm{mg} / \mathrm{kg}$ & $202.00 \pm 6.93$ & $210.50 \pm 12.99$ \\
Doseof $75 \mathrm{mg} / \mathrm{kg}$ & $104.50 \pm 10.10^{\mathrm{ab}}$ & $141.00 \pm 1.15^{\mathrm{a}}$ \\
Doseof $100 \mathrm{mg} / \mathrm{kg}$ & $119.00 \pm 2.31^{\mathrm{ab}}$ & $161.00 \pm 15.01^{\mathrm{a}}$ \\
Positive control & $158.50 \pm 2.02^{\mathrm{ab}}$ & $146.00 \pm 5.77^{\mathrm{a}}$ \\
Normal control & $96.00 \pm 6.35^{\mathrm{a}}$ & $41.00 \pm 2.65^{\mathrm{a}}$ \\
\hline
\end{tabular}

asignificantly different with the negative control group $(p<0.05)$, bame as a normal control group $(p>0.05)$

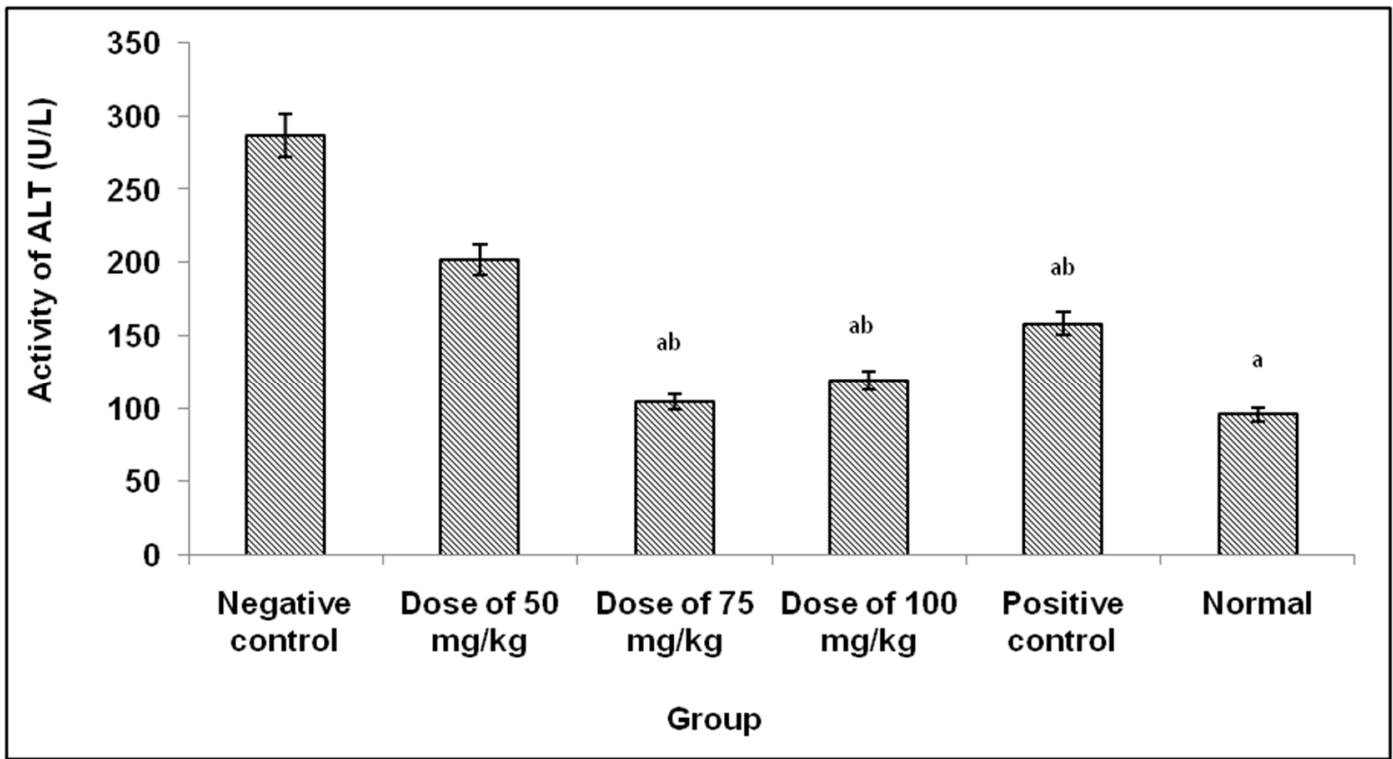




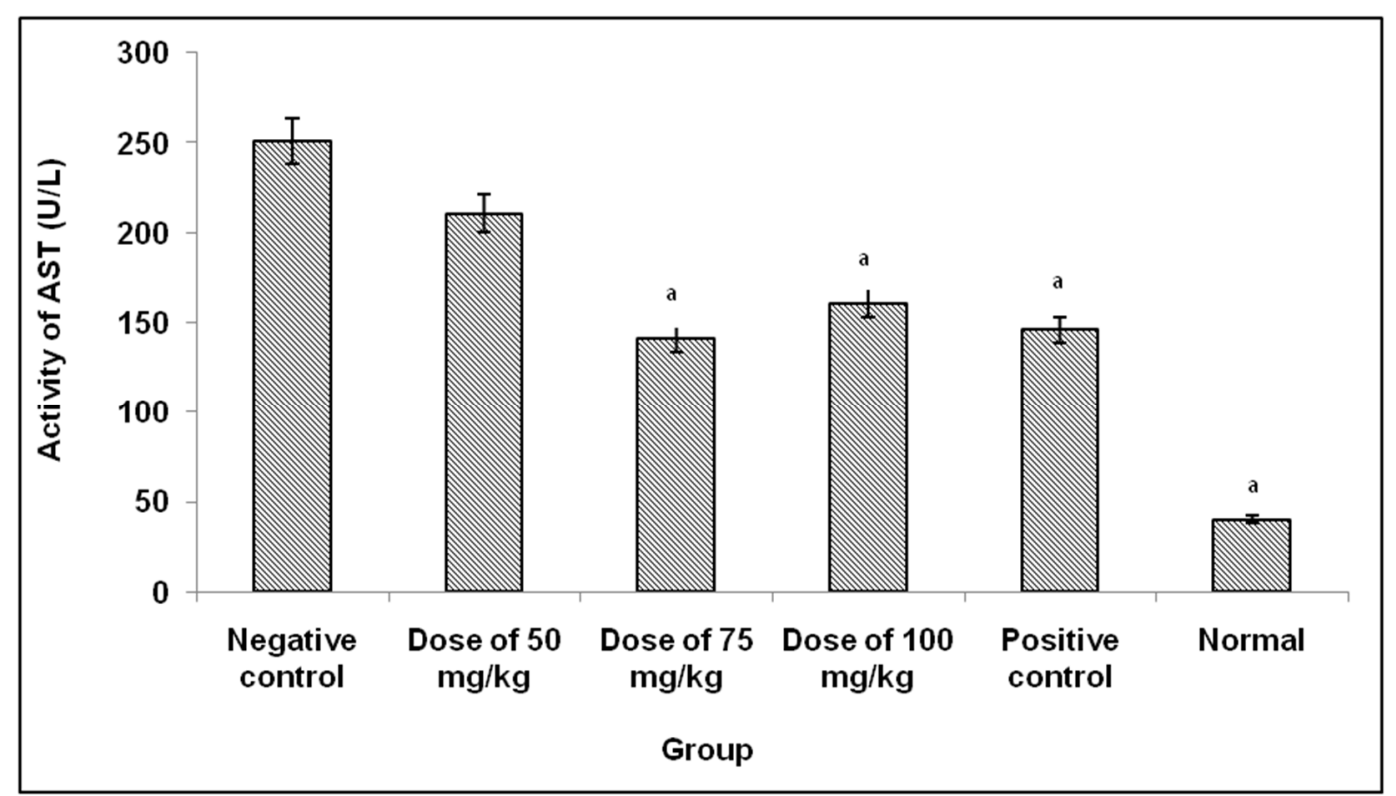

Fig. 3: Activity of ALT and AST from the rats on the $16^{\text {th }}$ day that have been induced by rifampicin and isoniazid

Based on table 3 and fig. 3, ALT of the negative control group increased significantly due to induction of rifampin and isoniazid compared to normal group $(\mathrm{p}<0.05)$. Administration combination of extracts at the dose of $50 \mathrm{mg} / \mathrm{kg}$ could not prevent elevation of ALT. Whereas at the doses of 75 and $100 \mathrm{mg} / \mathrm{kg}$, the combination of extracts was able to prevent increasing of ALT compared to negative control group $(\mathrm{p}<0.05)$. Moreover, the ALT value of those groups was the same as normal control.

It means that groups at the doses of 75 and $100 \mathrm{mg} / \mathrm{kg}$ had hepatoprotective activity. Besides ALT, AST increased significantly compared to normal group $(\mathrm{p}<0.05)$. Administration combination of extracts at the dose of $50 \mathrm{mg} / \mathrm{kg}$ could not prevent elevation of AST. Whereas at the doses of 75 and $100 \mathrm{mg} / \mathrm{kg}$, the combination of extracts was able to prevent the elevation of AST compared to negative control group $(\mathrm{p}<0.05)$.

\section{Histopathology}

Based on table 3 and fig. 3, ALT of the negative control group increased significantly due to induction of rifampin and isoniazid compared to normal group $(\mathrm{p}<0.05)$. Administration combination of extracts at the dose of $50 \mathrm{mg} / \mathrm{kg}$ could not prevent elevation of ALT. Whereas at the doses of 75 and $100 \mathrm{mg} / \mathrm{kg}$, the combination of extracts was able to prevent increasing of ALT compared to negative control group $(\mathrm{p}<0.05)$. Moreover, the ALT value of those groups was the same as normal control. It means that groups at the doses of 75 and $100 \mathrm{mg} / \mathrm{kg}$ had hepatoprotective activity.

Besides ALT, AST increased significantly compared to normal group $(\mathrm{p}<0.05)$. Administration combination of extracts at the dose of 50 $\mathrm{mg} / \mathrm{kg}$ could not prevent elevation of AST. Whereas at the doses of 75 and $100 \mathrm{mg} / \mathrm{kg}$, the combination of extracts was able to prevent the elevation of AST compared to negative control group $(\mathrm{p}<0.05)$

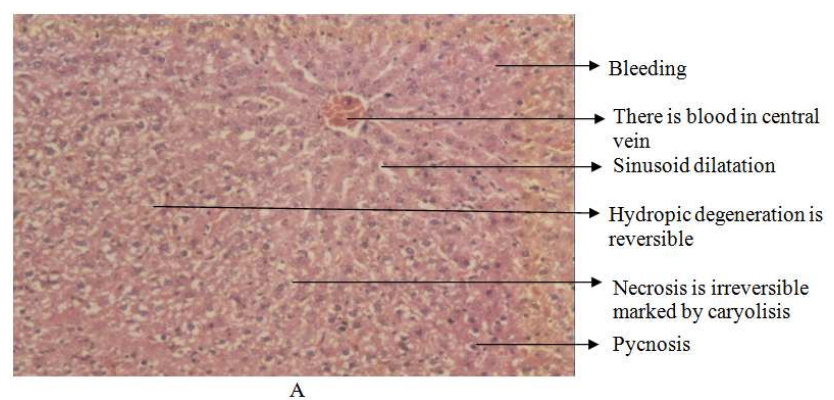

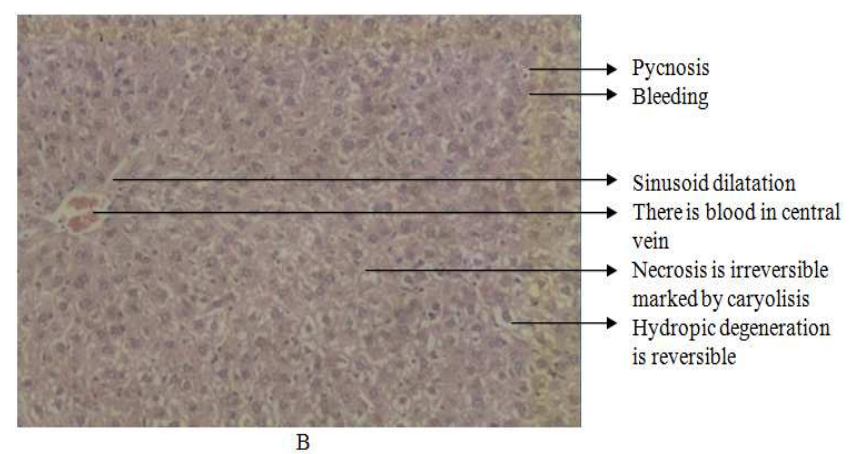

B
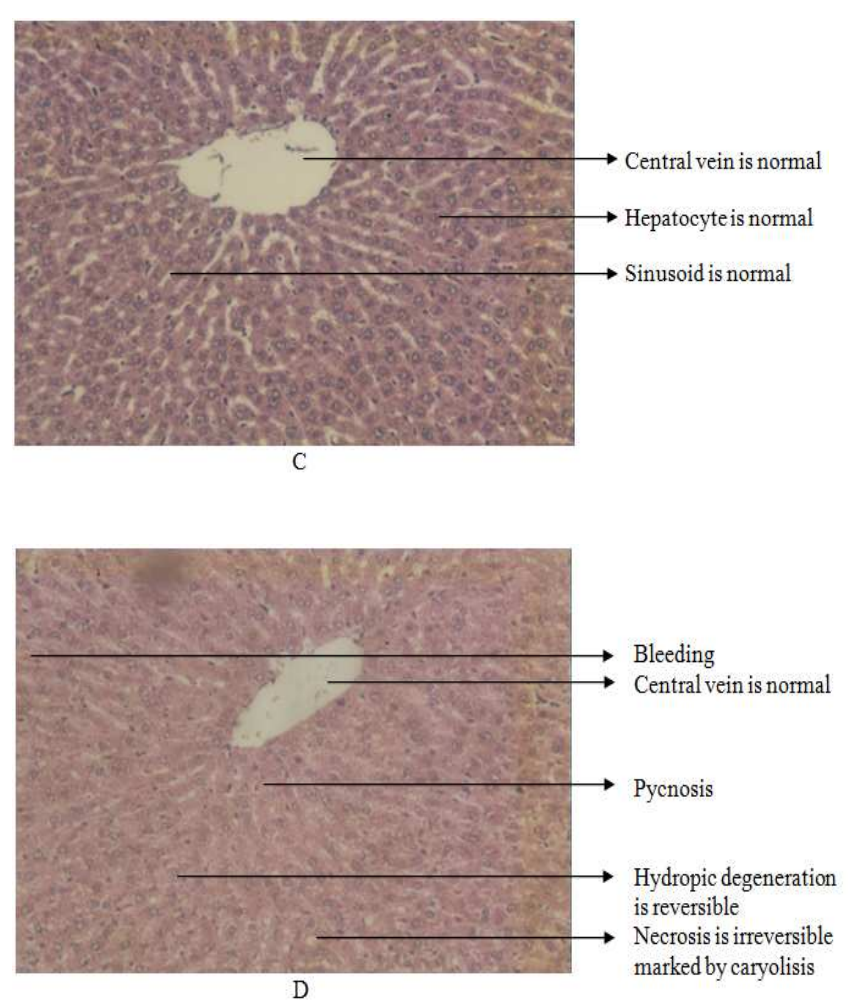

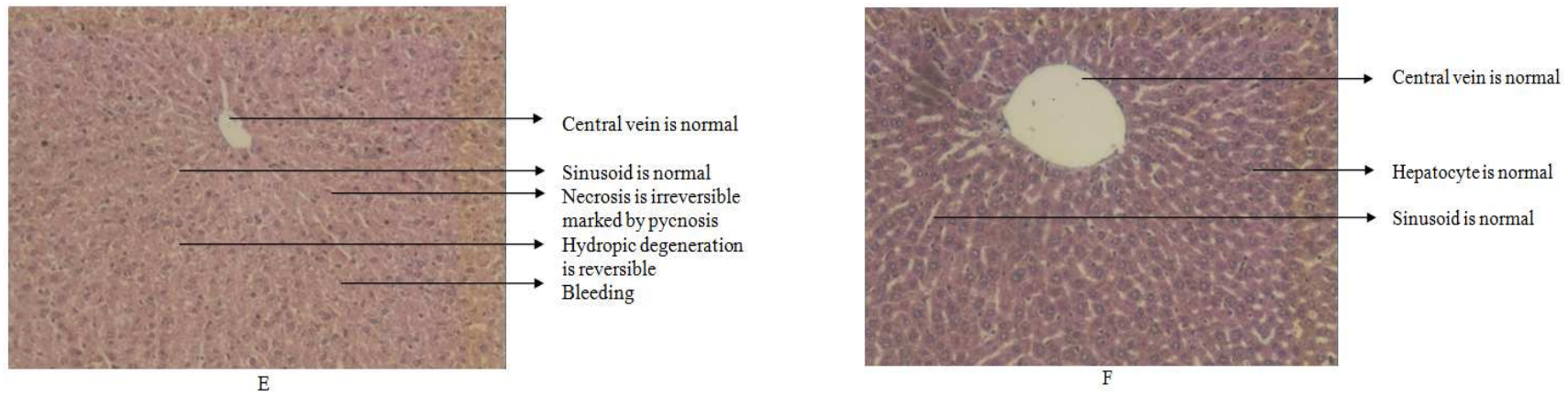

Fig. 4: Histopathology of the liver cell (10x10); (A) negative control; (B) dose of $50 \mathrm{mg} / \mathrm{kg}$; (C) dose of $75 \mathrm{mg} / \mathrm{kg}$; (D) dose of $100 \mathrm{mg} / \mathrm{kg}$; (E) positive control; (F) normal control

Histopathology result showed that there is blood in a central vein in negative control and group

at the dose of $50 \mathrm{mg} / \mathrm{kg}$ (fig. 4). Besides that, there is hydropic degeneration and necrotic in the liver cells. It indicates injury in the liver. In the groups at the doses of $75,100 \mathrm{mg} / \mathrm{kg}$, positive control and normal control, there are no either blood in a central vein or hydropic degeneration and necrotic in liver cells. It means that combination of ethanol extract of $C$. fel-terrae and rhizome of $C$. heyneanaat the doses of 75 and $100 \mathrm{mg} / \mathrm{kg}$ pose hepatoprotective activity.

\section{DISCUSSION}

Rifampin and isoniazid are first line therapy in tuberculosis disease [19-20]. The combination of these drugs in the treatment of tuberculosis disease will increase the risk of hepatotoxicity such as hepatitis [2]. Isoniazid hepatotoxicity is caused by metabolism in the liver which generates some metabolites such as hydrazine, acetylhydrazine, and other hydrazine metabolites that are free radicals [20]. Virtually CYP1A2 has a function to detox hydrazine, however, isoniazid hampers its activity. Rifampin is a strong inducer of the CYP450 system that can increase production of metabolites from other drug which is given concomitantly. Rifampin is able to elevate activity of CYP2E1 that relate to increasing of hydrazine production while it is combined with isoniazid [21]. Hydrazine lower antioxidant activity of glutation peroxidase as well as catalase. Next hydrazine will accelerate lipid peroxidation and cause hepatotoxicity [1].

Hepatotoxicity that is caused by enzyme inducer like rifampin can cause increasing in liver weight, hepatocellular hypertrophy, cell proliferation, and, frequently in long-term (lifetime) studies, hepatocarcinogenesis. These changes may be induced through a common mechanism of action involving activation of the nuclear hormone receptors constitutive androstane receptor (CAR), pregnane $\mathrm{X}$ receptor (PXR), or peroxisome activated receptor alpha (PPAR $\alpha)[22]$.

C. heyneana contains curcuminoid, which is comprised of curcumin, bisdemethoxycurcumin and desmethoxycurcumin. Curcumin is traditionally known having some effects totreat some diseases in human [23]. Curcumin is able to up-regulation of antioxidant enzyme gene expression, activation of the expressed genes and increase in the availability of glutathione (GSH) [24-25]. Curcuminoid is capable to scavenging the radical acetyl hydrazine and hydrazine which is generated by metabolism of isoniazid [26].

Methanolic extract of $C$. fel-terrae known contains alkaloids, cardiac glycosides, terpenoids, reducing sugar, tannins, phenolic, flavonoids and steroids [27]. Alkaloids in some plants known have significant cytoprotective effect against oxidative stress [28].

\section{CONCLUSION}

The combination of ethanolic extract of $C$. fel-terrae and $C$. heyneana can be considered as complement therapy for preventing liver injury which is caused by consuming anti-tuberculosis. Because combination at the doses of 75 and $100 \mathrm{mg} / \mathrm{kg}$ is able to protect the liver from damage induced by rifampin and isoniazid. The research can be continued to formulate the dosage form of these extracts.

\section{ACKNOWLEDGEMENT}

This research was supported by TALENTA Research Grants (Research No. 6051/UN5.1. R/PPM/2016) from the Universitas Sumatera Utara Indonesia.

\section{CONFLICT OF INTERESTS}

\section{Declared none}

\section{REFERENCES}

1. Saukkonen JJ, Cohn DL, Jasmer RM, Schenker S, Jereb JA, Nolan $\mathrm{CM}$, et al. An official ATS statement: hepatotoxicity of antituberculosis therapy. Am J Respir Crit Care Med 2006;174:935-52.

2. Yee D, Valiquette C, Pelletier M, Parisien I, Rocher I, Menzies D. Incidence of serious side effects from first-line antituberculosis drugs among patients treated for active tuberculosis. Am J Respir Crit Care Med 2003;167:1472-7.

3. Sastrapradja S, Soetjipto NW, Danimihardja S, Soejono R. Potential economic resources: potatoes. Res Project 1980;7:77.

4. Aspan R, Sherley, Napitupulu R, Wisaksono LS, Efizal, Mooduto $\mathrm{L}$, Herawaty $\mathrm{T}$, et al. Taxonomy collection of herbal medicine of field of herbal medicine Citeureup; 2008. p. 33.

5. Ge YW, Gao HM, Wang ZM. Advances in the study of genus curcuma. Zhongguo Zhong Yao Za Zhi 2007;32:2461-7.

6. Aspollah SM, Wah TS, Saad SM, Rashid NY, Rahmani M, Lajis $\mathrm{NH}$, et al. Bioactive sesquiterpenes from Curcuma ochrorhiza and Curcuma heyneana. Nat Prod Res 2010;24:838-45.

7. Saifudin A, Tanaka K, Kadota S, Tezuka Y. Sesquiterpenes from the rhizomes of Curcuma heyneana. J Nat Prod 2013;76:223-9.

8. Heneberg P. Use of protein tyrosine phosphatase inhibitors as promising targeted therapeutic drugs: Curr Med Chem 2009;16:706-33.

9. Dalimunthe A, Harahap U, Rosidah, Nasution PM. Evaluation of the diuretic activity of Picria fel-terrae Lour leaves extract. Asian J Pharm Clin Res 2015;8:204-5.

10. Satria D, Furqan M, Hadisahputra S, Rosidah. Combinational effects of ethyl acetate extract of Picria fel-terrae Lour and doxorubicin on T47D breast cancer cells. Int J Pharm Pharm Sci 2015;7:73-6.

11. Sihotang Y, Silalahi J, Hadisahputra S, Anjelisa P, Satria D. Cardioprotective effect of ethyl acetate extract of poguntano (Picria fel-terrae Lour.) Against doxorubicin-induced cardiotoxicity in rats: Int J Pharm Clin Res 2016;8 Suppl:46670.

12. Sitorus $P$, Harahap U, Nasution MP, Barus T. Isolation of $\beta$ sitosterol from an n-hexane extract of Picria fel-terrae Lour leave and study of its antidiabetic effect in alloxan-induced diabetic mice. Int J PharmTech Res 2014;6:137-41.

13. Harahap U, Husori DI, Marianne, Yuliasmi S, Patilaya P, Laila L, et al. Inhibitory effect to an ethanolic extract of Curanga felterrae (pugun tano) leaves on acetylcholine muscarinic-3 
receptors induced on isolated guinea pig tracheal. Asian J Pharm Clin Res 2017;10:95-8.

14. Harahap U, Marianne, Yuliasmi S. Studi Aktivitas Pugun Tano: Pendekatan histopatologi dan biomarker. Medan: Fundamental Research Report; 2015.

15. Zully FA, Harahap U, Marianne. Uji aktivitas hepatoprotektor ekstrak etanol Curcuma heyneana ValandZijpterhadap tikus Wistar jantan yang diinduksiparasetamol. Medan: Thesis; 2014.

16. Thampaty CM, Marianne, Harahap U. Aktivitas hepatoprotektif ekstrak etanol rimpang temu giring (Curcuma heyneanaVal and Zijp) terhadap tikus putih jantan yang diinduksi kombinasi isoniazid dan rifampisin. Medan: Thesis; 2015.

17. Aspan R, Sherley, Dwiyatmoko B, Sianipar A, Mardiaty, Usia T. Acuan sediaan herbal. Jakarta: Badan POM Republik Indonesia; 2011.

18. Marasani A. Hepatoprotective activity of Bauhinia variegate against isonized and rifampicin-induced toxicity in experimental rats. Int J Pharm Pharm Sci 2014;6:0975-1491.

19. Umar F, Basri C, Kasim F, Prajitno A, Hudoyo A, Kisdarjono H, et al. Pharmaceutical care untuk penyakit tuberkulosis. Jakarta: Kementrian Kesehatan Republik Indonesia; 2005.

20. Preziosi P. Isoniazid: metabolic aspects and toxicological correlates: Curr Drug Metab 2007;8:839-51.

21. Tostmann A, Boeree MJ, Aarnoutse RE, De Lange WCM, Van Der Ven AJAM, Dekhuijzen R. Antituberculosis drug-induced hepatotoxicity: concise up-to-date revie. J Gastroenterol Hepatol 2008;23:192-202.

22. Hall AP, Elcombe CR, Foster JR, Harada T, Kaufmann W, Knippel A, et al. Liver hypertrophy a review of adaptive (adverse and non-adverse) changes-conclusion from the 3rd International ESTP Expert Workshop. Toxicol Pathol 2012;40:971-94.
23. Hayakawa H, Minaniya $\mathrm{Y}$, Ito K, Yamamoto $\mathrm{Y}$, Fukuda T. Difference of curcumin content in Curcuma longa L. (Zingiberaceae) caused by hybridization with other Curcuma species. Am J Plant Sci 2011;2:111-9.

24. El-Bahr SM. Effect of curcumin on hepatic antioxidant enzymes activities and gene expressions in rats intoxicated with aflatoxin B1. Phytother Res 2015;29:134-40.

25. Syamsudin, Suyatna FD, Ganiswarna S, Sadikin M. Efek kurkumin terhadap aktivitas enzim glutation peroksidase mitokondria hati tikus yang diinduksi dengan butilhidroperoksida-tersier. Jurnal Kedokteran Maranatha 2006;6:33-9.

26. Wahyudi A. Pengaruh penambahan kurkumin dari rimpang temu giring pada aktifitas antioksidan asam askorbat dengan metode FTC: Akta Kimindo 2006;2:37-40.

27. Gohain N, Talukdar A, Baishnab M, Kalita MC. Phytochemical analysis and evaluation of the whole plant crude extracts of Curanga amara Juss. J Nat Prod Plant Resour 2014;4:18-23.

28. Xie Y, Zhang Y, Zhang LT, Zeng SX, Guo ZB, Zheng BD. Protective effects of alkaloid compounds from Nelumbinis plumula on tertbutyl hydroperoxide-induced oxidative stress. Molecules 2013;18:10285-300.

\section{How to cite this article}

- Marianne, Jessy Chrestella, Maria Andriani Ginting, Aminah Dalimunthe, Rosnani Nasution. Hepatoprotective activity combination of Curanga fel-terrae Lou leaves and Curcuma heyneana valeton and zijprhizome in rat induced by a combination of rifampin and isoniazid. Int J Pharm Pharm Sci 2017;9(5):23-28. 